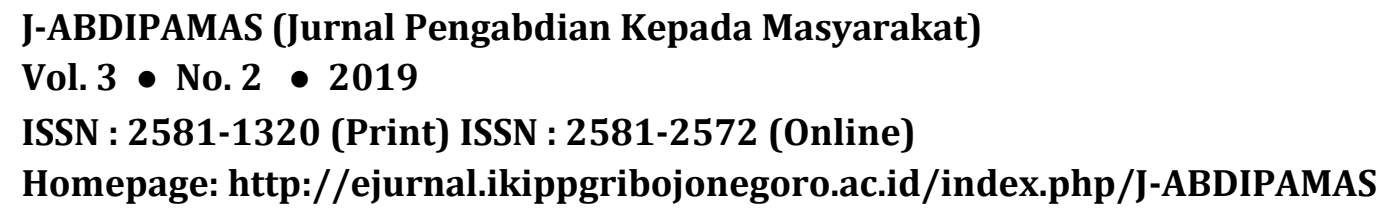

\title{
PELATIHAN PENGEMBANGAN MEDIA VIDEOSCRIBE DENGAN KONTEKS LOKAL DALAM MENGAJARKAN OBJEK MATEMATIKA BAGI MGMP SMA KABUPATEN BINTAN
}

\author{
Febrian $^{1}$, Puji Astuti ${ }^{2}$, Rindi Antika ${ }^{3}$ \\ ${ }^{1}$ Universitas Maritim Raja Ali Haji. Email: febrian@umrah.ac.id \\ 2Universitas Maritim Raja Ali Haji. Email: pujiastuti@umrah.ac.id \\ 3Universitas Maritim Raja Ali Haji. Email: rindiantika@umrah.ac.id
}

\begin{abstract}
The biggest challenge for Mathematics teachers is mastering Mathematics material with its abstract, logical, systematic and structured character for itself before teaching it to students. The teacher must mastering mathematical objects such as facts, concepts, operations, and principles and be able to describe these objects in every Math material. Not only that, the challenges from the pedagogical aspects also forced teachers to be able to think about how to teach abstract Mathematics material to students so that learning objectives are achieved. The choice of context and learning media is also an important aspect contributing to the success of the teaching and learning process. However, all these aspects are often a problem among teachers, especially at the high school level. Weaknesses in mastering the material as well as weaknesses in pedagogical aspects often arise in teaching mathematics. This certainly raises many ideas that can be discussed so that weaknesses can be minimized. One of them is improving understanding of Mathematics objects and emphasizing the choice of context and learning media. In this Community Service activity, the teacher is introduced to the use of videoscribe to develop media with local context in teaching Mathematics objects. Through this activity a change in understanding of mathematical objects, the roles and functions of health and learning media went better. In addition, participants can run videoscribe to create learning media that integrates all of the above aspects.
\end{abstract}

Keywords: local context, learning media, mathematics object, videoscribe

\begin{abstract}
ABSTRAK
Tantangan terbesar bagi guru Matematika adalah menguasai materi Matematika dengan karakternya yang abstrak, logis, sistematis dan terstruktur untuk dirinya sendiri sebelum mengajarkannya kepada siswa. Guru harus menguasai objek matematika seperti fakta, konsep, operasi, dan prinsip dan mampu menguraikan objek-objek tersebut di setiap materi Matematika. Tak hanya itu, tantangan dari aspek pedagogis juga memaksa guru untuk dapat memikirkan bagaimana cara mengajarkan materi Matematika yang abstrak tersebut kepada siswa agar tujuan pembelajaran tercapai. Pemilihan konteks dan media pembelajaran sekiranya juga menjadi aspek penting penyumbang keberhasilan proses pengajaran dan pembelajaran. Namun, semua aspek-aspek tersebut seringkali menjadi permasalahan di kalangan Guru terutama pada level SMA. Kelemahan penguasaan materi serta kelemahan dalam aspek pedagogis seringkali muncul dalam pengajaran matematika. Hal ini tentunya memunculkan banyak ide yang dapat diperbincangkan agar kelemahan dapat diminimalisir. Salah satunya adalah peningkatan pemahan terhadap objek Matematika serta penekanan pada pemilihan konteks dan media pembelajaran. Dalam kegiatan Pengabdian kepada Masyarakat ini, guru diperkenalkan pada penggunaan videoscribe untuk mengembangkan media dengan
\end{abstract}


konteks lokal dalam mengajarkan objek Matematika. Melalui kegiatan ini terjadi perubahan pemahaman mengenai objek matematika, peran dan fungsi kontkes dan media pembelajaran ke arah lebih baik. Di samping itu, peserta dapat menjalankan videoscribe untk membuat media pembelajaran yang mengitgrasikan kesemua aspek di atas.

Kata Kunci: konteks lokal, media pembelajaran, objek matematika, videoscribe

\section{PENDAHULUAN}

Matematika memiliki peran penting dalam Pendidikan. Hal ini tergambar dalam termuatnya matematika sebagai salah satu mata pelajaran yang diajarkan di sekolah mulai dari level pendidikan dasar hingga perguruan tinggi. Terkait peranannya, pembelajaran matematika di sekolah tidak hanya dimaksudkan untuk mencapai tujuan pendidikan matematika yang bersifat material, yaitu untuk membekali siswa agar menguasai matematika dan menerapkannya dalam kehidupan sehari-hari, namun lebih dari itu, pembelajaran matematika juga dimaksudkan untuk mencapai tujuan pendidikan matematika yang bersifat formal, yaitu untuk menata nalar siswa dan membentuk kepribadiannya (Mahmudi, 2009).

Matematika merupakan ilmu dasar yang memiliki karaktersitik tertentu. Menurut Soedjadi (1999) dalam (Mahmudi, 2009), karakteristik matematika diantaranya adalah memiliki objek abstrak, bertumpu pada kesepakatan, berpola pikir deduktif, memiliki simbol yang kosong arti, memperhatikan semesta pembicaraan, dan konsisten dalam sistemnya. Salah satu dari karaktersitik Matematika tersebut adalah objek matematika yang abstrak.

Dikenal adanya empat objek Matematika diantaranya: (1) fakta, (2) konsep, (3) keterampilan, dan (4) prinsip. Bell (1981) dalam (Mahmudi, 2009) mendefinisikan fakta sebagai kesepakatan; keterampilan sebagai prosedur atau operasi; konsep sebagai ide abstrak yang memungkinkan adanya penggolongan; dan prinsip sebagai objek komplit yang dapat berupa keterkaitan antar konsep. Penguasaan terhadap empat objek abstrak matematika ini merupakan salah satu faktor penentu dalam keberhasilan memahami matematika dan strukturnya.

Untuk dapat mengajarkan matematika dengan efektif diperlukan adaya strategi mengingat keabstrakan objek matematika tersebut. Beberapa hal diantaranya adalah penggunaan atau pemilihan konteks pembelajaran dan media/alat peraga pembelajaran. Konteks pembelajaran merupakan hal dasar yang dapat memungkinkan terjadinya proses belajar. Penggunaan konteks memainkan peranan utama dalam semua aspek dalam pendidikan, yaitu dalam pembentukan konsep, pembentukan model, aplikasi, dan dalam mempraktekkan keterampilan-keterampilan tertentu (Usdiyana, Purniati, Yulianti, \& Harningsih, 2009). Dalam pelaksanaan di kelas, konteks digunakan sejak awal dan terus menerus untuk membangun pemahaman siswa melalui learning trajectory dalam suatu proses pembelajaran (Usdiyana et al., 2009).

Selain penggunaan konteks, hal lain yang dapat menunjang pemahaman siswa terhadap matematika adalah penggunaan media pembelajaran. Digunakannya media dalam pembelajaran yaitu agar dapat menjembatani antara konsep-konsep matematika yang abstrak menjadi lebih kongkrit, sehingga siswa dapat memahami materi yang 
disajikan guru. Untuk itu, maka penggunaan media dalam proses pembelajaran sangat diperlukan demi tercapainya tujuan pembelajaran secara optimal (Amir, 2014).

Di era revolusi industri 4.0 guru ditantang untuk dapat memikirkan bagaimana menciptakan perwajahan pembelajaran yang dapat mengakomodasi pemahaman siswa terhadap matematika dengan lebih baik. Salah satu aspek yang dapat dimanfaatkan adalah penggunaan produk teknologi dalam menunjang proses pembelajaran. Salah satunya adalah program Videoscribe. Jika dilihat dari karakternya, Videoscribe sangat menjanjikan sebagai media pembelajaran karena bersifat multimedia (ada tampilan visual dan audio). Videoscribe merupakan sebuah software yang digunakan guru dan siswa membuat animasi berbentuk papan tulis untuk meningkatkan minat dan retensi dalam pembelajaran. Videoscribe dapat meningkatkan pembelajaran dengan mengkombinasikan audio dan visual (Rahmawati, Soegimin, \& Kardi, 2016). Dengan karakternya ini Videoscribe terasa menjanjikan dalam mnegajarkan objek abstrak dalam materi matematika.

Hasil penelitian menunjukkan bahwa siswa masih kesulitan dalam memahami materi matematika (Jamal, 2019). Hal ini didukung dengan hasil pengamatan lapangan dan wawancara terhadap guru SMA Kabupaten Bintan. Banyak hal yang menjadi faktor penyebab hal ini terjadi. Selain dari karakter abstrak objek matematikanya sendiri yang memungkinkan siswa sulit menguasainya, ternyata factor bersumber dari guru terasa penting untuk ditelaah. Fakta menemukan bahwa banyak guru yang masih kesulitan dalam mengurai dan memetakan objek-objek abstrak dalam materi matematika tertentu. Sementara kemampuan ini sangat dituntut dalam kurikulum 2013 dan pemahaman terkait objek matematika abstrak ini haruslah tertuang eksplisit di Rencana Proses Pembelajaran (RPP). Kelemahan dalam menguasai objek-objek matematika ini berdampak pada setting pembelajaran yang dibawakan guru di dalam kelas. Memang sebagian guru telah membawa proses pembelajaran sesuai tuntutan kurikulum 2013 yang cenderung mengarahkan pembelajaran dengan karakter discovery maupun pemecahan masalah. Namun, proses pembelajaran itu berjalan sekedar untuk memenuhi setiap sintaks model pembelajaran. Seringkali pembahasan objek-objek matematika dengan pendekatan mengajar untuk masing-masingnya yang cocok dalam proses pembelajaran menjadi aspek yang tidak mendapatkan penekanan. Padahal salah satu factor keberhasilan menguasai matematika dalah menguasai objek-objeknya.

Disamping itu, kelemahan dalam proses pembelajaran adalah kurangnya penggunaan konteks relevan dengan kehidupan siswa untuk membangun pemahaman (Lidinillah, 2013; Murtiyasa, 2015). Hal ini mengakibatkan matematika terasa jauh dari siswa sehingga siswa sulit memahaminya. Terakhir, kemampuan guru dalam menggunakan media untuk menunjang proses pembelajaran masih terasa lemah. Banyak praktek mengajar yang terjadi dimana siswa jarang mendapatkan media pembelajaran untuk mereka membangun pemahaman.

Keseluruhan situasi ini terasa mampu menggerakkan sejumlah pihak, dalam hal ini dosen pendidikan matematika FKIP UMRAH untuk dapat memperbaiki perwajahan pembelajaran. Salah satu kegiatan yang dapat dilakukan adalah dengan menyelenggrakan pengabdian kepada masyarakat. Dalam hal ini, guru menjadi sasaran kegiatan untuk 
mereka dapat memperbaiki praktek mengajar dalam kelas yang dapat berdampak pada proses pembelajaran. Mengingat karakter matematika, objeknya yang abstrak, pentingnya penggunaan konteks dan media pembelajaran, maka melalui analisis situasi ini, maka kegiatan bertema "Mengembangkan Media Ajar Berbasis Videoscribe Dengan Konteks Lokal Dalam Mengajarkan Objek Matematika Bagi MGMP SMA Kabupaten Bintan“ dirasa perlu untuk segera dilaksanakan.

\section{METODE PELAKSANAAN}

Metode yang digunakan dalam pengabdian masyarakat dalam bentuk rangkaian kegiatan yang dilaksanakan secara berkesinambungan dalam dua hari kerja, yaitu pada tanggal 8 dan 9 Agustus 2019. Berdasarkan hasil analisis situasi dihadapkan dengan solusi yang telah digagas pada bagian sebelumya, maka ditetapkan metode atau bentuk pelaksanaan kegiatan seperti yang diberikan dalam tabel berikut

Tabel 1. Metode pelaksanaan kegiatan

\begin{tabular}{|c|c|c|}
\hline No & Solusi Permasalahan & Metode Pelaksanaan \\
\hline 1 & $\begin{array}{l}\text { Pemantapan penguasaan objek-objek abstrak matematika dalam } \\
\text { topik matematika sekolah }\end{array}$ & Pemaparan Materi dan Diskusi \\
\hline 2 & $\begin{array}{l}\text { Pengarahan mengenai mengenai pentingnya penggunaan konteks } \\
\text { dan media pembelajaran serta memperkenalkan videoscribe } \\
\text { sebagai salah satu alat pembelajaran }\end{array}$ & $\begin{array}{ll}\text { - } & \text { Pemaparan Materi dan } \\
& \text { Diskusi } \\
\text { - } & \text { Demonstrasi }\end{array}$ \\
\hline 3 & $\begin{array}{l}\text { Mendampingi guru-guru yang tergabung dalam MGMP } \\
\text { Matematika tingkat SMA di Kabupaten Bintan dalam } \\
\text { memanfaatkan videoscribe dalam mengembangkan media } \\
\text { dengan menggunakan konteks lokal untuk mengajarkan objek- } \\
\text { objek matematika }\end{array}$ & $\begin{array}{ll}- & \text { Hands on peserta } \\
- & \text { Pembimbingan intensif } \\
\text { - } & \text { Presentasi peserta }\end{array}$ \\
\hline 4 & Melakukan evaluasi pelaksanaan kegiatan menggunakan angket. & $\begin{array}{l}\text { Penyebaran angket kepada } \\
\text { peserta }\end{array}$ \\
\hline
\end{tabular}

\section{HASIL DAN PEMBAHASAN}

Pada kegiatan hari pertama, 8 Agustus 2019, selama 8 jam kegiatan dilakukan sejumlah kegiatan sebagai berikut:

a. Pemaparan pertama

Kegiatan pertama diawali dengan pemaparan penguasaan objek-objek abstrak matematika dalam topik matematika Sekolah Menengha Atas (SMA). Kegiatan dilakukan dengan mengupas karakteristik matematika berikut objek-objek abstrak meliputi fakta, konsep, prinsip, dan operasi dengan teknik ekspositori, dan eksplorasi. Guru diarahkan untuk dapat membedakan keempat objek tersebut dan dibawa untuk memikirkan apa dampak dari mengetahui dan penguasai keempat objek tersebut.

Melalui pemaparan materi ini, diketahui bahwa hanya sebagian kecil guru yang dapat memberikan makna dua dari empat objek matematika seperti fakta dan konsep serta memberikan contohnya pada materi SMA. Secara umum, guru belum dapat membedakan ke empat objek tersebut dengan jelas Hal ini ditambah pula dengan 
kenyataan bahwa hampir semua guru tidak dapat membedah sebuah topik matematika serta mengurai konetn tersebut ke dalam empat kategori objek. Beranjak dari kondisi tersebut, pemateri membantu guru membangun pemahaman terhadap objek matematika tersebut melalui sejumlah contoh. Selanjutnya guru diminta untuk dapat menetapkan dan mengurai objek-objek matematika dalam topik matematika sekolah tertentu.
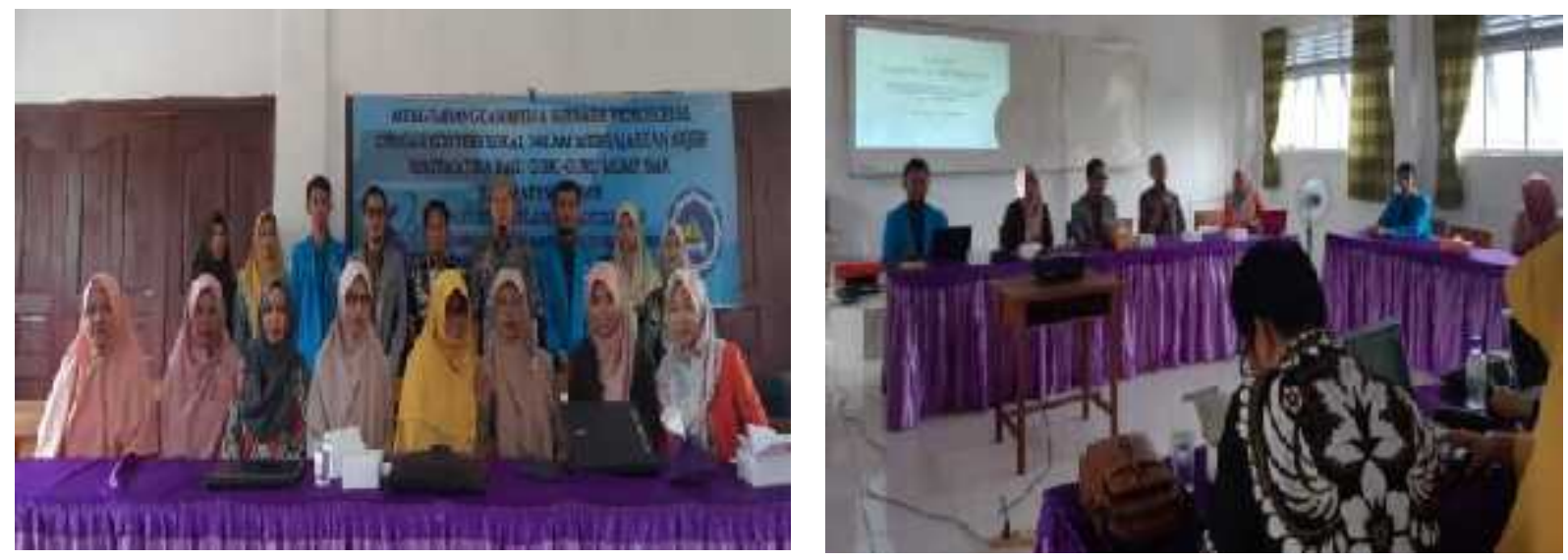

Gambar 1. Dokumentasi kegiatan hari pertama

Melalui sesi pertama kegiatan pertama pemaparan, guru perlahan mulai dapat membangun pemahaman mereka mengenai objek matematika serta dapat memberikan contoh untuk setiapnya. Lebih jauh lagi melalui penugasan singkat bersifta mandiri, guru mulai dapat menguraikan topik matematika yang mereka pilih ke dalam sejumlah objek matematika yang mungkin mereka petakan.

b. Pemaparan kedua

Kegiatan pemaparan dilanjutkan dengan pengarahan mengenai pentingnya penggunaan konteks dan media pembelajaran serta memperkenalkan videoscribe sebagai salah satu alat pembelajaran. Dalam kegiatan ini guru dibawa untuk memahami esensi menggunakan konteks dalam proses pembelajaran. Dalam sesi ini, sejumlah hasil penelitian etnomatematika dengan kearfian lokal hasil penelitian dosen dan mahasiswa disajikan untuk memancing pemahaman guru mengenai konsep konteks pembelajaran yang bersifat lokal. Selanjutnya, guru diminta untuk dapat memberikan pemisalan konteks yang dapat digunakan untuk membangun konsep di kalangan siswa. Konteks yang diminta diupayakan berasal dari konteks lokal.

c. Pemaparan ketiga

Pemaparan dilanjutkan kepada penggunaan teknologi di era revolusi industry 4.0 yang dapat menunjang proses pembelajaran. Sejumlah program dan aplikasi disajikan serta konsep bimbingan belajar online juga dibahas. Namun bagian inti terkait paparan tentang esensi penggunaan media dalam proses pembelajaran berbasis teknologi dalam hal ini penggunaan videoscribe dilakukan. Setelah kupas tuntas dilakukan untuk membuat guru mengenal videoscribe, maka selanjutnya videoscribe diperdalam melalui demonstrasi langkah perlangkah dimana pemateri diasistensi oleh sejumlah anggota dari dosen dan mahasiswa. Sesi ini diakhir dengan diskusi dan tanya jawab. 


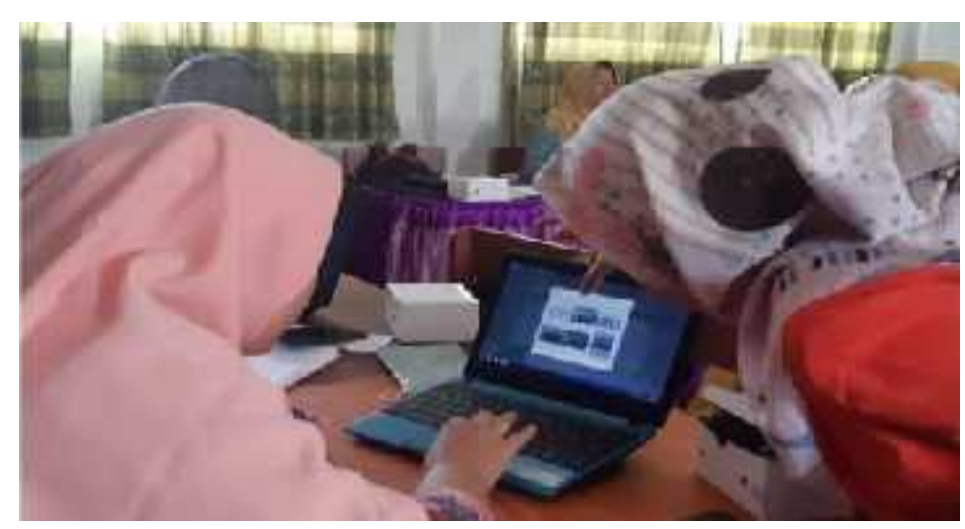

Gambar 2. Demonstrasi langkah-langkah instalasi dan penggunaan

Pada kegiatan hari kedua, 9 Agustus 2019, selama 8 jam kegiatan dilakukan sejumlah kegiatan sebagai berikut:

\section{a. Pendampingan}

Kegiatan pertama hari kedua dimulai dengan mendampingi guru-guru yang tergabung dalam MGMP Matematika tingkat SMA di Kabupaten Bintan dalam memanfaatkan videoscribe dalam mengembangkan media dengan menggunakan konteks lokal untuk mengajarkan objek-objek matematika. Kegiatan ini meminta peserta untuk dapat mengintegrasikan pengetahuan mengenai objek matematika, konteks dan media pembelajaran, serta penggunaan videoscribe sehingga dapat menghasilkan media yang dapat mengajarkan siswa mengenai fakta, konsep, prinsip, dan operasi dalam materi pelajaran matematika. Para peserta mendapatkan pembimbingan insentif selama kegiatan.
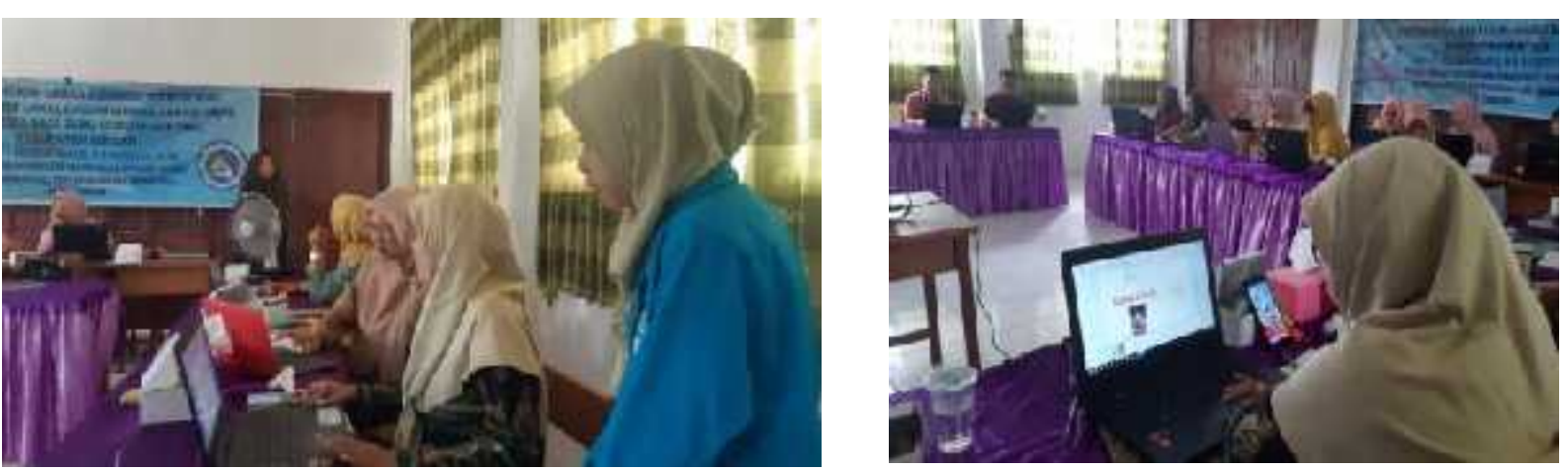

Gambar 3. Pendampingan para peserta

Dalam kegiatan ini, secara umum guru telah mampu mengoperasikan videoscribe untuk mencipatkan media pembelajaran. Guru telah memilih topik matematematika serta mngurai sejumlah objek di dalamnya. Dengan kreativitas pemilihan konteks lokal, sejumlah guru berhasil membuat media videsocribe dengan baik. Sejumlah hasil eksplorasi guru dalam menggunakan videocribe untuk menghasilkan media pembelajaran untuk mengajarakan objek matematika dengan konteks dapat dilihat pada gambar berikut. 

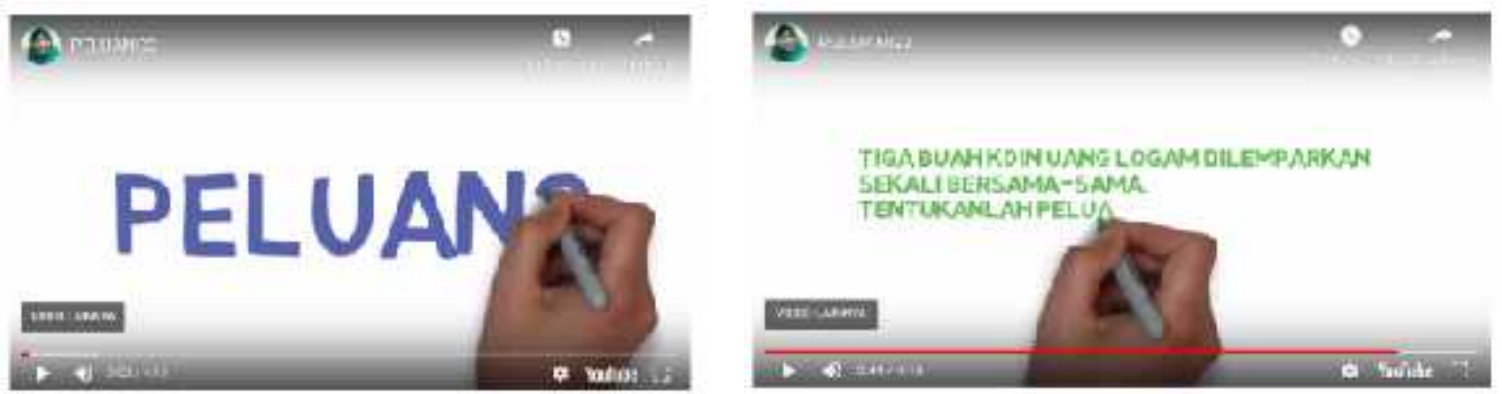

Gambar 4. Hasil eksplorasi peserta PKM didiseminasikan melalui Youtube

b. Evaluasi kegiatan

Kegiatan diakhir melalui sesi evaluasi kegiatan bersama para peserta yang dilanjutkan dengan penyebaran angket online berbasis google form yang memiliki focus pada pelaksanaan PkM berisi pesan, kesan, dan sejumlah hal yang telah dipelajari peserta selama kegiatan PkM dijalankan yang bermanfaat secara langsung bagi peserta.

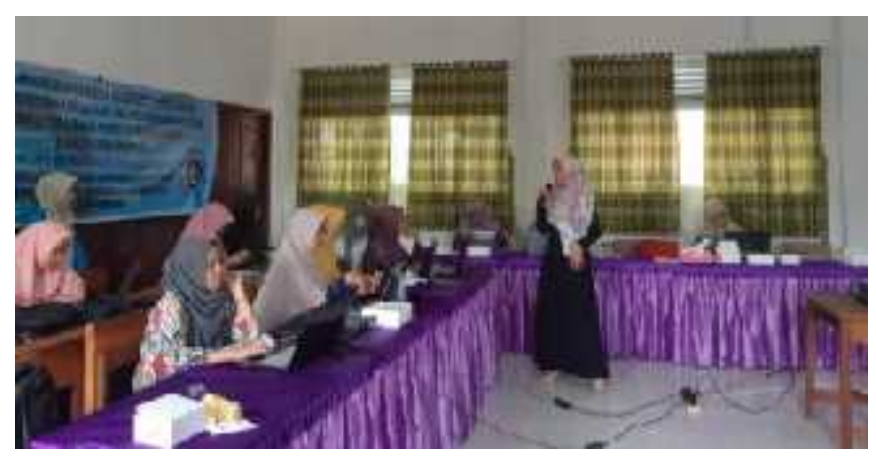

Gambar 4.5 Dokumentasi kegiatan akhir

Secara umum, peserta menilai kegiatan PkM berjalan dengan baik sekali, semntara hanya $5 \%$ diantaranya menilai cukup. Secara ringkas rekapitulasi penilaian peserta terhadap kegiatan PkM ditunjukkan oleh diagram berikut.

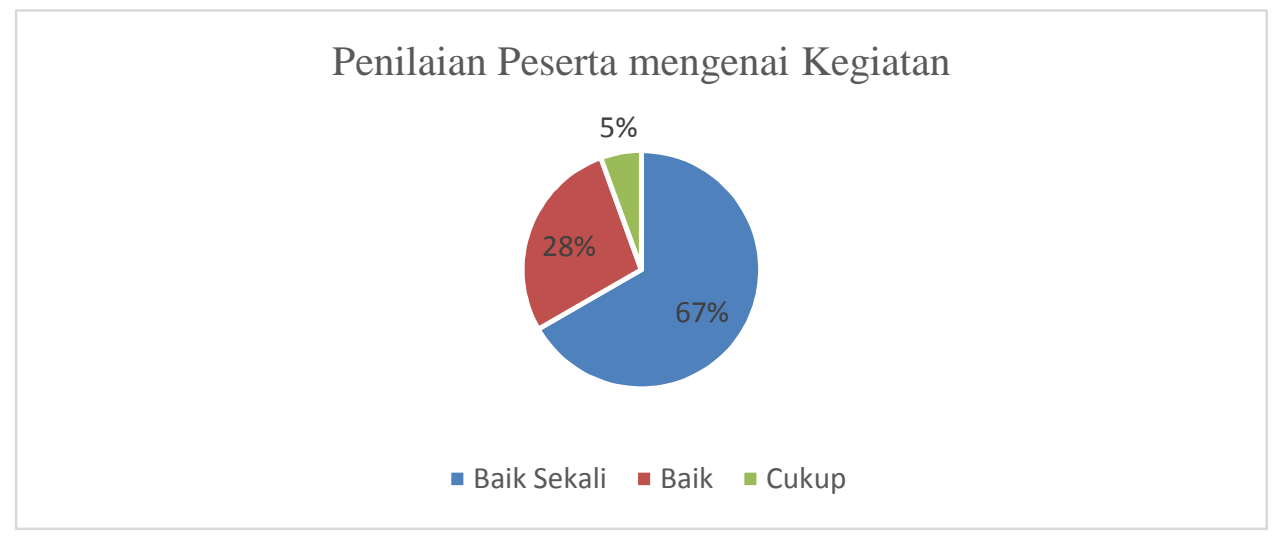

Gambar 4.6 Diagram penilaian umum terhadap PkM 
Sejumlah penilaian lain dilakukan terhadap PkM oleh peserta dari aspek pemateri seperti kemampuan dalam menarik partisipasi peserta; kejelasan dan kemduahan dalam penyampaian materi. Secara umum, respon dari peserta terhadap setiap butir tersebut lebih dari $50 \%$ berpendapat sangat setuju yang bermakna pemateri telah menjalankan fungsi pemaparnya dengan sangat baik. Detil penilaian disajikan ringkas dalam bentuk diagram berikut.
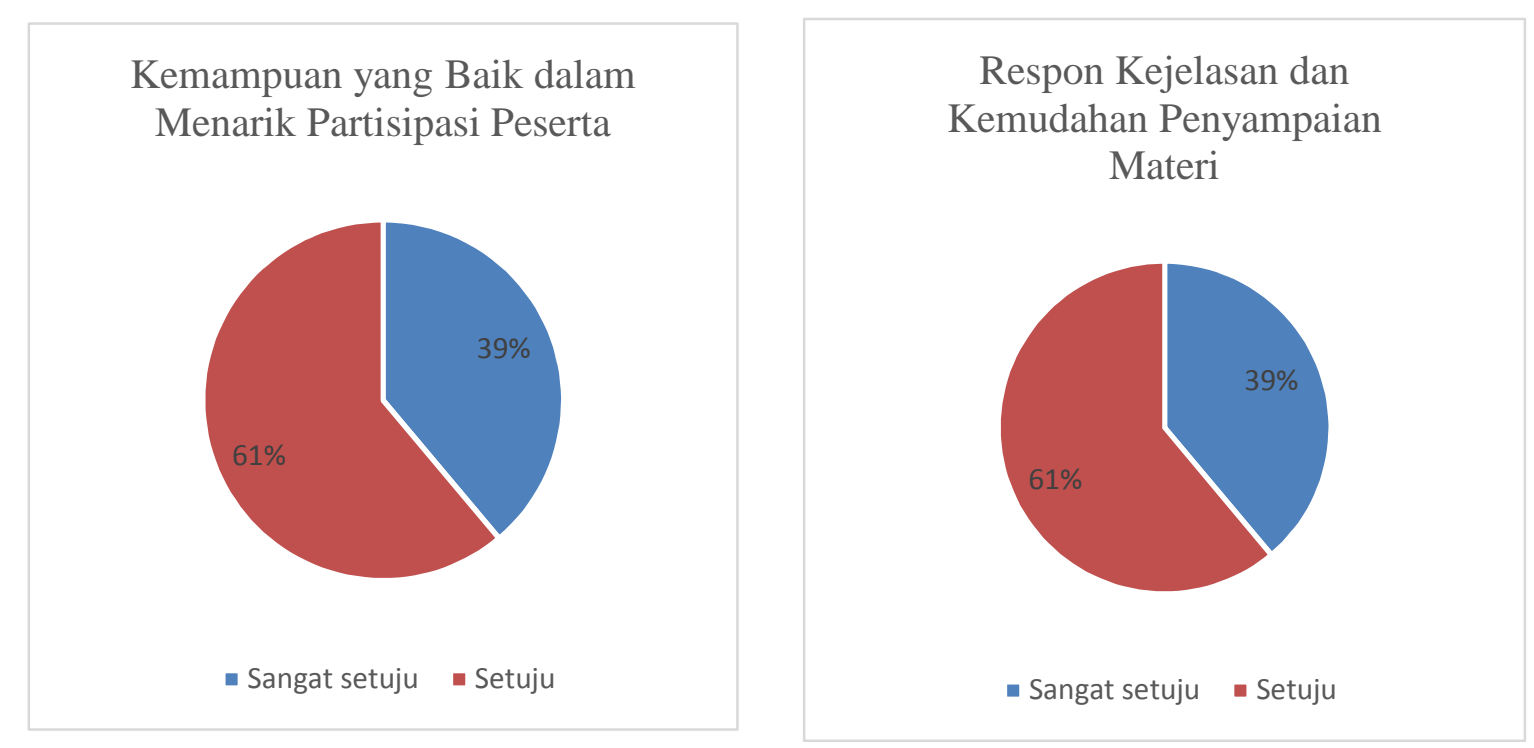

Gambar 4.7 Penilaian terhadap pemateri pada kegaiatn PkM

Di samping itu, penilaian lain dilakukan terhadap PkM oleh peserta dari kejelasan tujuan kegiatan dan kejelasan serta keterurutan konten yang disajikan dalam kaitannya terhadap membantu pemahaman para peserta. Secara umum, untuk setiap aspek penialain, lebih dari 50\% menyatakan sangat setuju bahwa kegiatan memiliki tujuan yang jelas. Begitu pula halnya dengan kejelasan materi. Terdapat lebih dari 50\% peserta meberikan respon sangat setuju terkait kejelasan materi dan urutan yang disusun baik dalam menunjang pemahaman para peserta. Detil penilaian disajikan ringkas dalam bentuk diagram berikut.
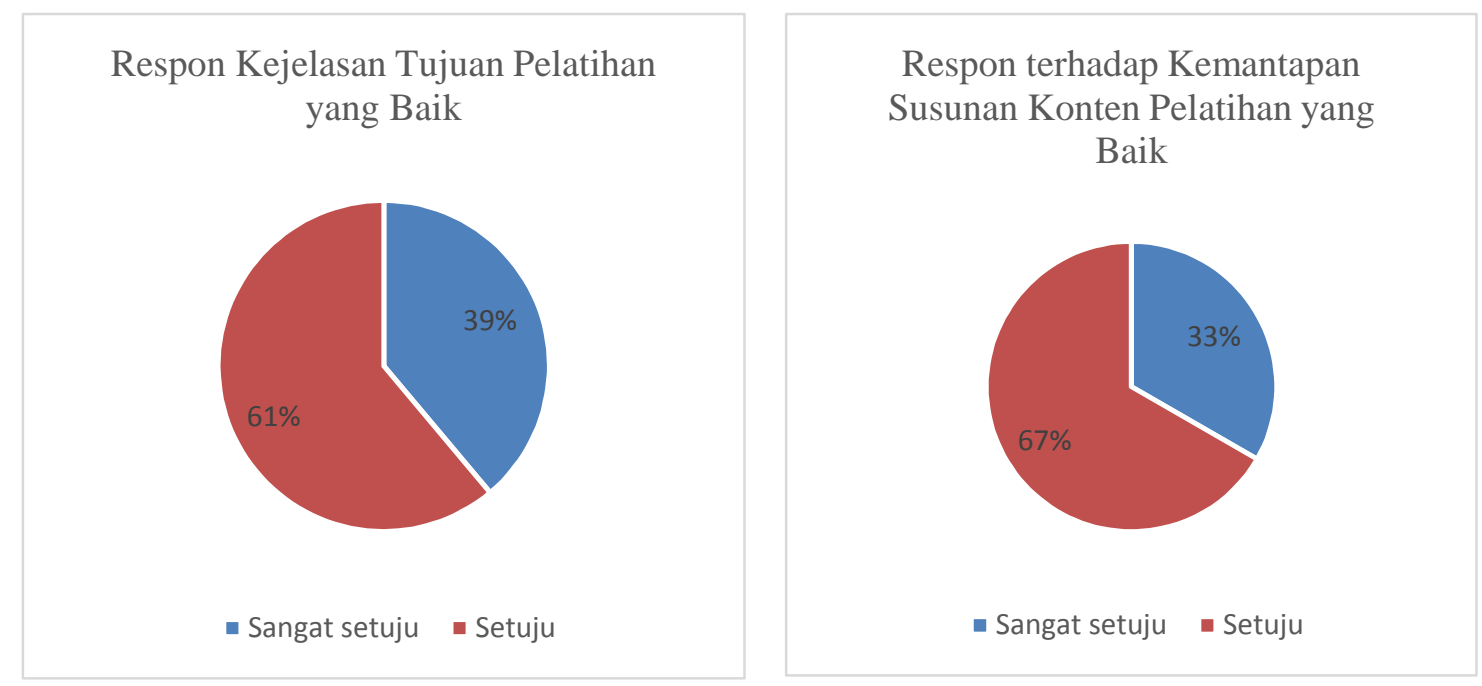

Gambar 4.8 Penilaian terhadap tujuan dan konten materi PkM 
Melalui kegiatan PkM diperoleh informasi bahwa 100\% peserta menyatakan ketertarikan mereka dalam penggunaan videoscribe untuk mengembangkan media pembelajaran matematika berbasis teknologi dalam mengajarkan objek matematika. Secara umum peserta menilai videoscribe memiliki prospek yang baik dalam mengubah perwajahan pembelajaran matematika di era revolusi industry 4.0. Di samping itu, sebanyak 29\% peserta menyatakan bahwa mereka terkesan dan mengambil manfaat dari pemaparan tentang objek matematika. Sedangkang sebanyak $71 \%$ peserta menilai bahwa pemaparan materi mengenai videsocribe telah mnearik perhatian mereka serta telah menambah wawasan mereka mengenai penggunaan teknologi dalam proses pembelajaran.

Berdasarkan hasil kegiatan PkM yang telah dibahas di atas, dapat dikatakan terjadi sejumlah perubahan dari aspek pemahaman dan wawasan peserta kegiatan. Pertama, perubahan terjadi pada pemahaman mengenai objek matematika. Melalui kegiatan diskusi dan tanya jawab pemaparan mengenai objek matematika, para peserta telah mampu mengindentifikasi objek-objek matematika dengan baik. Dengan demikian, pemahaman bahwa matematika memiliki sifat yang abstrak (Soedjadi dalam Mahmudi, 2009) berdasarkan objeknya telah dimiliki oleh peserta kegiatan. Kedua, wawasan mengenai peranan konteks dalam pembelajaran juga mngalami perubahan. Secara umum, peserta telah mampu mengidentifikasi peranan dan fungsi penggunaan konteks pembelajaran. Peserta menyimpulkan bahwa konteks pembelajaran mampu mengantarkan siswa pada konsep matematika yang akan dipelajarai. Hal ini senada dengan pendapat Usdiyana, Purniati, Yulianti, dan Harningsih (2009) mengenai penggunaan konteks yang memainkan peranan utama dalam semua aspek dalam pendidikan, yaitu dalam pembentukan konsep, pembentukan model, aplikasi, dan dalam mempraktekkan keterampilan-keterampilan tertentu.

Ketiga, perubahan terjadi pada pemahaman mengenai media pembelajaran serta fungsinya dalam proses pembelajaran. Respon dominan yang diberikan oleh peserta menunjukkan bahwa media pembelajaran dengan basis teknologi dalam hal ini videoscribe mampu membuat pembelajaran menjadi lebih menarik oleh karena tampilannya yang sangat interaktif. Hal ini sekiranya senada dengan pendapat Rahmawati, Soegimin, dan Kardi (2016) yang menyatakan bahwa Videoscribe dapat meningkatkan pembelajaran dengan mengkombinasikan audio dan visual. Hal tersebut menjadikan peserta menilai bahwa media videoscribe mampu membantu siswa memahami objek matematika dengan baik dalam topik matematika yang mereka pelajari sehingga sangat potensial untuk digunakan dalam proses pembelajaran. Sekiranya pendapat ini secara umum senada dengan Amir (2014) yang menyatakan bahwa penggunaan media dalam proses pembelajaran sangat diperlukan demi tercapainya tujuan pembelajaran secara optimal. Dengan demikian, dapat dikatakn telah terjadi peningkatan wawasan penggunaan teknologi dalam mengembangkan media pembelajaran di kalangan guru-guru yang tergabung MGMP Matematika Kabupaten Bintan dalam hal mengajarkan objek Matematika menggunakan Konteks Lokal. 


\section{SIMPULAN}

Melalui kegiatan PkM dengan tema mengembangkan media berbasis videoscribe dengan konteks lokal dalam mengajarkan objek matematika yang melibatkan peserta guru-guru tergabung dalam MGMP Matematika Kabupaten Bintan yang diselenggarakan di SMA negeri 1 Bintan Timur pada tanggal 8 - 9 September 2019, dapat disimpulkan bahwa kegiatan PkM telah berhasil berjalan dengan baik dan telah mencapai tujuan kegiatan ditandai dengan terjadinya perubahan pemahaman peserta mengenai objek matematika, peran dan fungsi konteks pembelajaran, peran dan fungsi media pembelajaran ke arah lebih baik, serta mengenal videoscribe dan mampu menggunakannya dalam menciptakan media pembelajaran yang dapat menunjang proses pembelajaran matematika.

\section{UCAPAN TERIMA KASIH}

Ucapan terima kasih kepada Universitas Maritim Raja Ali Haji (UMRAH) atas pendanaan penuh kegiatan melalui skema Pengabdian kepada Masyarakat (PkM) yang dikelola oleh LP3M UMRAH. Ucapan terimakasih juga diberikan kepada mahasiswa kami Pani Ridwan, Al Aziz Yandamika, dan Raja Noviani yang turut berpartisipasi dalam lancarnya kegiatan PkM.

\section{DAFTAR RUJUKAN}

Amir, A. (2014). Pembelajaran matematika SD dengan menggunakan media manipulatif. FORUM PAEDAGOGIK Jurnal Pendidikan Agama Islam, 6.

Jamal, F. (2019). Analisis Kesulitan Belajar Siswa dalam Mata Pelajaran Matematika Pada Materi Peluang Kelas XI IPA SMA Muhammadiyah Meulaboh Johan Pahlawan. MAJU: Jurnal Ilmiah Pendidikan Matematika, 1(1).

Lidinillah, D. A. M. (2013). Pembelajaran berbasis masalah (problem based learning). Jurnal Pendidikan Inovatif, 5(1), 17.

Mahmudi, A. (2009). Pengembangan Pembelajaran Matematika. Online). Tersedia: Http://staff. Uny. Ac. id/sites/default/files/tmp/Pengembangan\% 20Pemb, 20.

Murtiyasa, B. (2015). Tantangan pembelajaran matematika era global.

Rahmawati, F., Soegimin, W. W., \& Kardi, S. (2016). Pengembangan Perangkat Pembelajaran Fisika Model Inkuiri Terbimbing Berbantuan Videoscribe Pada Materi Kalor Untuk Meningkatkan Hasil Belajar Siswa SMAN 1 Kedungwaru. JPPS (Jurnal Penelitian Pendidikan Sains), 5(2), 1039-1047.

Usdiyana, D., Purniati, T., Yulianti, K., \& Harningsih, E. (2009). Meningkatkan kemampuan berpikir logis siswa SMP melalui pembelajaran matematika realistik. Jurnal Pengajaran MIPA, 13(1), 1-14. 